DOI: $10.17805 /$ zpu.2016.4.4

\title{
Анализ культурных ресурсов: мягкая мощь и идентичность *
}

\author{
Н. Н. ФЕДОТОВА
}

(МОСКОВСКИЙ ГОСУДАРСТВЕННЫЙ ИНСТИТУТ МЕЖДУНАРОДНЫХ ОТНОШЕНИЙ

МИНИСТЕРСТВА ИНОСТРАННЫХ ДЕЛ РОССИИ)

В статье предпринята попытка анализа понятий «мягкая мощь» и «идентичность», их значения в комплексе категорий, концептуализирующих культурный ресурс развития. Данное исследование продолжает направление авторских исследований понятий «идентич-

* Публикация подготовлена в рамках поддержанного РГНФ научного проекта № 15-03-00732 «Социально-философский анализ культурных ресурсов российского развития».

The article was prepared with financial support from Russian Foundation for the Humanities, grant No. 15-03-00732 “Cultural Resources of Russian Development: A Socio-Philosophical Analysis”. 
ность», «коды и константы культуры», «культурный и символический капитал», значимых для анализа черт мягкой мощи.

Показывается, что мягкую мощь страны можно трактовать как производную от ее идентичности. Автор применяет выделенные испанским социологом М. Кастельсом легитимизирующие, оппозиционные и проективные типы или функции идентичности и на этой основе, используемой как методологический инструментарий, дает характеристику российской мягкой мощи. Вводятся понятия легитимизирующих, оппозиционных и проективных типов или функций мягкой мощи. «Строительными блоками» для этих функций мягкой мощи являются некоторые, в том числе и мало исследованные, факторы, такие как прецедентные феномены культуры, культурные константы, культурный капитал, идентичность, коды культуры.

Проанализировано значение фактора культуры, внутренней и внешней политики для формирования мягкой мощи. Показано, что российская мягкая мощь является оппозиционной и проективной по отношению к доминирующему мировому порядку и вместе с тем легитимизирующей для российского контекста. Это важно для избежания международных конфликтов, ибо сдерживание в век ядерного оружия, обеспечиваемое балансом сил, не является абсолютным гарантом. Представлены основные вехи динамики американской и российской мягкой мощи с 1990 года по настоящее время и пределы влияния мягкой мощи. Ключевые слова: мягкая мощь; идентичность; культура; ресурс; Россия; США; легитимизирующая мягкая мощь; оппозиционная мягкая мощь; проективная мягкая мощь

\section{BВЕАЕНИЕ}

$\mathrm{B}$ данной статье автор продолжает разрабатывать концептуальную схему работы с рядом категорий, описывающих культурные ресурсы стран. Базовые категории, включающие представление о кодах культуры, идентичности и ее процессуальном характере, мягкую мощь (силу), константы культуры и культурный капитал, уже были рассмотрены автором (Федотова, 2015). Поскольку то, что воспроизводится в относительно новом понятии мягкой мощи вообще и российской мягкой мощи в частности, подвержено изменениям, автор намеренно ограничивается обращением к литературе, касающейся российской мягкой мощи, преимущественно недавних лет. Аругая причина этого состоит в том, что антагонизм между мягкой мощью Запада и российской мягкой мощью проявлен в Ираке, Египте, на Украине, а сегодня подошел к опасным пределам отношений между Россией и Западом в Сирии. Существующая напряженность способствовала появлению новой, не изученной литературы - как статей в научных журналах, так и книг, например малоизвестной пока, хотя и изданной на русском языке книги Аж. Ная «Будущее власти» (Nye, 2011). Быстрая динамика событий создает резкую смену ситуаций и решений, приводя нередко к выводам, которые теоретически еще не были подтверждены. Автор статьи пытается опереться на теоретические источники, которые дают дополнительные основания как для концептуализации проблемы мягкой мощи, так и для ее адекватного применения, а также связывают мягкую мощь с идентичностью, формируя важный культурный ресурс.

\section{МЯГКАЯ МОЩЬ И ИАЕНТИЧНОСТЬ КАК КУАЬТУРНЫЕ РЕСУРСЫ}

Обозначенная в данном подзаголовке связь мягкой мощи и идентичности не исследована. Остановимся на двойственной - теоретической и практической - природе обсуждаемых понятий и их взаимодействии.

Концепция мягкой мощи разработана американским политологом Аж. Наем. В 1990 г. он ввел понятие мягкой мощи (силы) в книге «Призванные лидировать: изменяющаяся природа американской власти» (Nye, 1990). После выхода книги Аж. Ная о мягкой мощи в 2004 г. этот концепт получил активное применение (Най, 2006). 
В 2003 г. он ввел термин «умная мощь», используя это понятие для оправдания вторжения в Ирак. Умная мощь в международном пространстве определяется совместной работой как мягкой, так и жесткой мощи. В 2011 г. им опубликована книга «Будущее власти», в которой он развивает идеи взаимодействия мягкой мощи и умной мощи (Nye, 2011). Все эти понятия вошли в арсенал политико-социологических исследований анализа потенциала стран в области международных отношений, а также борьбы с терроризмом и архаикой в политической сфере. В этом последнем случае Най, как и его последователи, надеялись на стремление арабских стран к демократии и на то, что они к ней придут.

Методологически значимым для анализа международных отношений стало обсуждаемое Наем различие между властью и ресурсами. Ааже наличие ресурсов еще недостаточно для достижения цели. Их потенциальная роль становится актуальной, когда власть действительно может их использовать для достижения целей. Най выделяет три аспекта власти, проявляющиеся в отношениях между ее субъектами. Эти аспекты он называет «лицами» власти» и относит к ним иниииирование изменений, контроль над повестками дня и возможность установления приоритетов (там же: 10-11). Первый аспект состоит в том, что власть предполагает способность повдиять на изменение поведения контрагента в его исходных намерениях, что является характеристикой твердой мощи. Это формулируется следующим образом: «А использует угрозы или вознаграждения для изменения поведения В относительно исходных предпочтений и стратегий агента В. В это знает и чувствует воздействие власти А» (там же: 14). Вmорой аспект показывает возможности оказать влияние на изменение чужих приоритетов таким образом, чтобы они захотели того, чего хотите вы, и вам не пришлось бы заставлять их изменить свое поведение: «А контролирует повестку действий таким образом, чтобы ограничивать возможность выбора стратегии агентом В. В может знать или не знать об этом» (там же). Однако если те, на кого направлена власть, «принимают легитимность институтов социального дискурса, сформировавшего повестку дня, то они не будут чувствовать себя принужденными...» (там же: 13). Если повестка дня подразумевает угрозу принуждения или обещания вознаграждения, тогда это будет всего лишь стороной первого аспекта власти, отмечает Най. Уверенность в «легитимности этой повестки делает второй аспект власти частично включающим мягкую мощь, способность добиться желаемых целей с помощью... убеждения и достижения позитивной привлекательности» (там же). Третий аспект: «А помогает создавать и придавать форму базовым убеждениям, представлениям и предпочтениям агента В. Маловероятно, что В осознает это или ощущает воздействие власти A» (там же: 14). Иначе, если оказываемое на оппонента давление, а тем более если он его ощущает, воспринимается явно, то оно не является мягкой мощью.

Второй и третий аспекты власти относятся к мягкой мощи, «к способности получить предпочитаемые результаты с помощью... таких инструментов, как определение повестки, убеждение и привлечение» (там же: 16). Сложность состоит в том, что не всякая мягкая мощь понимается как таковая, ибо трудно определить условия добровольного формирования предпочтений и даже сами интересы привлекаемой стороны. Най выделяет структурное и агентское измерения власти: «...страна может пытаться привлекать других с помощью действий, например, публичной дипломатии, но она также может привлекать других с помощью структурных воздействий собственного примера или того, что может быть названо эффектом “сияющего града на холме” ” (там же: 17). В данном случае он использует метафору восприятия США своим насе- 
лением как совершенного общества, распространенную в Америке со времен ее отцов-основателей (Уткин, Кузнецова, 2010). Най показывает значимость информационно-коммуникационного аспекта для стратегий как мягкой, так и умной мощи. Он приводит пример того, как средства массовой коммуникации (СМК) представляли себе ближневосточные события в 1991 и 2003 гг. В 1991 г. монополия западных СМК, особенно CNN и BBC, приводила к тому, что их нарратив событий был доминирующим, однако после появления Al Jazeera - альтернативного источника информации эта монополия была утеряна, и уже встречались такие варианты описания событий, как «американские войска вторглись в Ирак», а не только «американские войска вошли в Ирак» (Nуе, 2011: 20). Эти утверждения приводят к совершенно разным возможностям формирования предпочтений.

Целостное определение мягкой мощи Ная, выведенное из анализа трех рассмотренных аспектов, состоит в том, что это - «способность воздействовать на других с помощью... установления повестки, убеждения и позитивной привлекательности с целью достижения предпочитаемых результатов» (там же: 21). Мягкая мощь часто основана на таких неуловимых ресурсах, как «институты, идеи, ценности, культура, и воспринимаемая легитимность политики» (там же). Жесткая мощь включает в себя другие ресурсы: силу и деньги, совокупность военных и экономических стратегий. Отношения между мягкой и жесткой мощью не заданы автоматически, будучи более сложными: «...неуловимые ресурсы, такие как патриотизм, мораль и легитимность, сильно влияют на военную способность бороться и выигрывать» (там же). Жесткая мощь, однако, может сформировать ресурсы, в свою очередь, создающие мягкую мощь в будущем (там же). Верна и обратная закономерность. Но одна мягкая мощь не может обеспечить успехи во внешней политике, нужна и умная мощь (там же: 22). Най подчеркивает, что мягкая мощь работает только в определенном историческом контексте. Ааже в США существует тенденция опираться преимущественно на первый аспект власти (инициирование изменений), которая имеет корни в американской политической культуре и институтах: «Ни один политик не хочет казаться “мягким”» (там же: 18).

Переходя ко второму элементу культурных ресурсов - идентичности, остановимся на признанных в науке позициях испанского социолога М. Кастельса. Он выделяет три типа (и три источника) коллективной идентичности, которые, на наш взгляд, могут выступать как ее функциональные свойства. Это, во-первых, идентичность, которая называется легитимизирующей. Она предлагается обществу государством и другими доминирующими институтами для рационализации, легитимации и укрепления своего господства. Во-вторых, существует идентичность сопротивления, которая формируется силами, считающими себя ущемленными со стороны институтов господства и выступающими против них. Она строится на принципах, отличающихся или противоположных тем, которые реализованы в существующих общественных институтах. В-третьих, все больше проявляет себя проективная идентичность, состоящая в том, что социальные акторы строят новую идентичность на основе имеющихся в обществе культурных продуктов, пытаясь переопределить свое положение в обществе, меняя тем самым ограничивающую их ранее социальную структуру общества в целом (Castells, 2010: 8).

То, что начинается как идентичность сопротивления в один исторический период, может трансформироваться в проективную идентичность, которая бросает вызов легитимизирующей идентичности и меняет образ общества, став доминантной (там же). 
В настоящее время идентичности сопротивления, по мнению Кастельса, «исходно конструируемые на основе исторических укорененных представлений (бог, нация, этничность, локальность), усилили свое значение в социальных конфликтах и социальной организации мира» (там же: XXVI). Он отмечает широкомасштабное развитие проективных идентичностей, стремящиеся изменить общество с опорой на новые ценностные ориентации (там же).

Таким образом, идентичности сопротивления, равно как и легитимизирующие и проективные, конструируются на основе элементов примордиального (этничность, локальность, язык, родство, территория), гражданственного (нация, социальные практики, традиции) и сакрального (бог, рациональность) кодов идентичности, введенных Ш. Айзенштадтом (см.: Федотова, 2015: 37-38; Eisenstadt, 2003). «Строительным материалом» новых идентичностей, по мнению Кастельса, являются элементы исторического, географического, биологического характера, которые используются для формирования «производящих и репродуктивных институтов, коллективной памяти, персональных фантазий, аппарата власти и религиозных откровений» (Castells, 2010: 7). Кастельс показывает, что социальное конструирование идентичности всегда осуществляется в контексте властных отношений, поэтому три вида идентичности, которые он выделяет, связаны с отношениями доминирующих институтов и представлений (там же). Таким образом, они имеют сходство с тем, что Най называет мягкой мощью. Удивительным тут является то, что политология, в данном случае в лице Ная, и социология в лице Кастельса шли разными путями, имели отличающийся фокус исследований (политологи опирались на власть и политику, а социологи - на структуры, институты, ценности), но пришли к сходным результатам. Най с помощью понятия мягкой мощи обратился к тому, что раньше изучали в социологии - ценности, предпочтения, культурный капитал. А Кастельс, будучи социологом, вышел в сферу политики, политизировал идентичности, показав, что за каждой идентичностью стоит определенная политика.

Кастельс показал работу этих идентичностей на уровне общества, а мы в данной статье применяем эти категории к понятию мягкой мощи и покажем, как они работает на мировой арене.

Аостаточно редко встречаются исследования, концептуализирующие более одной категории культурных ресурсов. Речь идет или о мягкой мощи, или об идентичности, или о культурном капитале и пр. В этом смысле выделяется несколько работ, в которых предпринимаются попытки связать интересующие нас концепты. Британский исследователь В. Феклюнина предлагает интересный подход, который связывает мягкую мощь и коллективную идентичность. По ее мнению, оценить силу мягкой мощи одной страны по отношению к другой можно путем изучения степени принятия или отрицания коллективной идентичности первой страны аудиториями второй страны. В данном случае принятие идентичности - это признание легитимности чьей-либо мягкой мощи.

В. Феклюнина полагает, что мягкая мощь является не собственностью какого-либо одного актора. Она выступает производной отношений между двумя или более акторами (Feklyunina, 2015: 4), т. е. является тем, что происходит между ними. Аж. Най сказал: «...мы любим тех, кто на нас похож» (Nye, 2011: 92). То есть, если кто-то не принимает нашу идентичность, или видит ее как чужую, не принадлежащую собственному сообществу, нам будет сложнее продвигать свою интерпретацию событий (Feklyunina, 2015: 6). В связи с этим Феклюнина предлагает использовать концепцию 
«нормативной власти», т. е. способности какой-либо страны или группы стран «переопределить международные нормы со своей точки зрения» (там же). Фактически речь идет о процессуальности мягкой мощи и ее взаимодействии с идентичностью.

Мягкая мощь может «возрастать, уменьшаться и исчезать по мере эволюции идентичностей и интересов» (там же). Упомянутый автор прозорливо заметила: «Несмотря на то что государства часто выбирают инструментальный подход для проецирования своей идентичности на другие страны, ни одно государство не может получить полную монополию на нарратив, т. к. существует множество конкурирующих нарративов идентичности» (там же: 7).

Роль государства в разработке и продвижении мягкой мощи очень высока. Феклюнина показывает, что, артикулируя какой-то вариант нарратива идентичности, можно мобилизовать одни структуры, ослабляя другие. «Они сигналят элитам и публике другого государства (намеренно или нет) об интересах, лежащих в основе его политики... С одной стороны, государства не могут монополизировать нарративы идентичности, и их собственное понимание “себя" и чувство “мы” определяется существующими культурными структурами, которые были сформированы определенными историческими событиями. С другой стороны, процессы конструирования и трансформации коллективной идентичности (хотя они часто продвигаются сознательными усилиями культурных или политических элит), не зависят от их инструментальных попыток навязать эти идентичности сверху вниз» (там же).

Аудиторий в стране, на которую направлена мягкая мощь, может быть много, и они могут по-разному определять ее привлекательность: «...мягкая мощь государства А по отношению к государству В будет значительной, если проецируемое государством А определение “мы”, артикулируемое в официальном дискурсе и проявляемое (намеренно или нет) в практических действиях, будет приниматься всеми основными дискурсами идентичности государства В» (там же: 8). Сила мягкой мощи А не является постоянной величиной: она меняется в зависимости от степени принятия аудиториями проецируемой коллективной идентичности государством В, а также от способности этих аудиторий влиять на процесс принятия решения (там же). Таким образом, «сила мягкой мощи государства А будет максимальной, если все основные дискурсы идентичности государства В, в том числе дискурс идентичности, артикулируемый властью... принимают нарратив коллективной идентичности государства А» (там же). Следует подчеркнуть, что кризис идентичности является препятствием для мягкой мощи.

\section{АМЕРИКАНСКАЯ И РОССИЙСКАЯ МЯГКАЯ МОЩЬ}

Во времена холодной войны два противника - США и СССР - боролись за идеологическое, военное, культурное и экономическое влияние. В плане культурного влияния были выработаны стратегии того, что тогда называлось публичной дипломатией. СССР, как показывает Аж. Най, обладал культурной привлекательностью, которую обеспечивали, в том числе, победа во Второй мировой войне, идеология коммунизма, борьба с колониализмом, хорошее образование и наука, спортивные достижения, покорение космоса и высокая культура (Най, 2006: 109-112, Федотова, 2015: 44-46). Конечно же, речь шла и об использовании жесткой мощи әкономических и военных ресурсов. США создавали свой центр притяжения и использовали стратегии твердой и мягкой мощи для продвижения идей открытого общества, демократии и прав человека, капитализма, науки и технологий и своей высокой и массовой культуры. После распада СССР и падения коммунизма в России ситуация резко поменялась. 
Аж. Най в книге 2011 г. показал значимость сочетания мягкой и жесткой мощи, а также возможность формирования мягкой мощи в результате применения военной и экономической составляющих. Сочетание мягкой и жесткой мощи особенно необходимо для сверхдержавы, как показывает американский исследователь А. Каллео: «Амбициозная мягкая мощь без жесткой мощи, необходимой в качестве гаранта уважения, может сделать страну претенциозной и бессильной. Жесткую мощь тяжело поддерживать без мягкой мощи, делающей ее законной и желанной» (Calleo, 2009: 67).

Рассмотрим некоторые вехи в динамике мягкой мощи США и России с 1990-х годов (с распада СССР) до настоящего времени.

В 1990 году, как мы уже отметили, выходит книга Аж. Ная «Призванные лидировать», в которой он показал, что США меняют форму мощи, переходя от применяемой ранее основанной на принуждении жесткой формы до мягкой формы, основанной на привлекательности. Специфика мягкой мощи США состояла главным образом в том, что они являлись магнитом для глобального притока мозгов и предпринимательской активности (Nye, 1990). Упомянутый выше исследователь A. Каллео отмечает: «Развал СССР радикально обесценил привлекательность советской марксистской модели и уменьшил привлекательность социалистической и коммунистической моделей в целом. После падения марксизма капитализм стал по умолчанию рассматриваться как победитель. Его победа сделала США триумфатором в наибольшей степени потому, что американские лидеры привыкли представлять свою страну как носителя глобального капитализма. Такая роль, конечно, благословила американскую мягкую мощь» (Calleo, 2009: 68). То есть можно говорить о триумфальности национальной идентичности США того периода. Каллео показывает, что задолго до того, как США стали моделью глобализации, они были привлекательны как «земля возможностей», т. е. место, где новоприбывшие оказывались вне ограничений классовых иерархий и достигали экономических успехов. Такой образ США за последние десятилетия распространился и на неевропейские страны - Аатинскую Америку и Азию. «Неоконсерваторы администрации Буша трансформировали этот образ Америки в энергичную мягкую мощь, экспортируемую в качестве революционной идеологии для подрывания экономически нелиберальных и политически репрессивных режимов, особенно на Ближнем Востоке» (там же).

В 2004 г. Най публикует статью «Падение американской мягкой мощи» (в том же году выходит его книга «Мягкая мощь»). В ней Най показывает нарастание антиамериканских настроений по миру и падение мягкой мощи США, т. е. способности Америки «привлекать других с помощью легитимности политики США и ценностей, лежащих в ее основе» (Nye, 2004: 16). Он объясняет, что к такой ситуации привела неспособность США управлять политикой мягкой мощи в информационном обществе, в то время как привлекательность американской культуры, коммуникационных технологий, образования в мире могли бы этому способствовать. А. Каллео показывает, что высокая культура США «вряд ли может считаться уступающей культуре какой-либо другой страны - в искусстве и науках или в области высшего образования и научных исследований - не в последнюю очередь потому, что США исторически была убежищем для преследуемых талантов со всего мира» (Calleo, 2009: 67). «Но достижения Америки в высокой культуре, - подчеркивает A. Каллео, - конкурируют с достижениями других стран и вряд ли оправдывают претензии Америки на однополярный статус. Американская популярная культура, однако, настолько широко распространена, что может претендовать на уникальный глобальный статус» (там же). 
Однако у любой мягкой мощи, в том числе у американской, есть определенные ограничения. Обратимся к некоторым из них: можно ли преобразовать для мировых масс привлекательность массовой культуры США в мягкую силу? «Скорее иностранцы часто находят наиболее привлекательными те аспекты американской массовой культуры, которые противостоят политическим, социальным и военным институтам Америки. В любом случае, восхищению американской популярной культурой слабо препятствует популистский антиамериканизм. Террористы едят в Макдоналдсе, носят синие джинсы и скачивают популярную музыку» (там же). Кроме того, одним из главных факторов роста антиамериканизма являются попытки насадить американскую модель как универсальную: «В целом американскую национальную модель с ее вдохновляющей либеральной культурой, моралью, предпринимательской әнергией... не так легко перенести куда-либо... Представители администрации Буша, продвигавшие эти идеи, являются консерваторами. С недоверием относящиеся к социальной инженерии дома, за границей они ведут себя как старомодные либеральные революционеры, истово верующие в то, что экономически и политически свободные рынки еще раз совершат магические действия, как только падут дьявольские преграды диктатуры и монополии» (там же: 69).

В 2016 г. вышла статья Ж.-П. Аемана «Коллапс мягкой мощи США - Глобальное влияние» (Lehmann, 2016: Электронный ресурс). Автор показал, что в начале XXI века «все, казалось, идет по-американски», так как рост экономической мощи Японии замедлился, СССР распался, а весь мир принял американский капитализм вместе с глобализацией. В области внешней политики трагическая атака на здание башенблизнецов в 2001 г. вызвала спонтанную глобальную симпатию и солидарность с США. Однако США не удержали мягкую мощь на таком уровне: помешало провальное вторжение в Ирак в 2003 г., не только нелегальное (без санкции Совбеза ООН), но и ошибочное. Финансовый кризис 2008 г. способствовал потере мягкой мощи американского капитализма и финансов, повлекшей утрату их легитимности. В области внутренней политики - феномен Трампа, рост социального неравенства внутри США, уменьшение доли среднего класса, не работающие каналы вертикальной социальной мобильности. Это был путь, на котором США потеряли имидж «земли обетованной» (там же). Сказанное является свидетельством того, что легитимизирующая функция мягкой мощи США все более подвергается делегитимизации и эрозии в связи с проблемами страны во внешней и внутренней политике.

Россия встретила 1990-е годы новой страной, находящейся в глубоком кризисе идентичности, экономики, внутренней и внешней политики. «...Страна, которая была маяком социалистических движений по всему миру, превратились за несколько лет в разрушенное в моральном и социальном плане государство, съеденное капиталистическими финансами и олигархами, пришедшими к власти через “шоковую терапию”, приватизацию и либерализацию Бориса Ельцина», - считает итальянский исследователь П. Чаппони (Италия ... , 2016: Электронный ресурс). Современная Россия никогда не существовала в нынешних границах. Она была шире и географически, и культурно, что создавало и до сих пор создает проблемы для самоидентификации и выработки национальной идеи. Все это негативно повлияло на чувство «мы» и на представление россиян о месте страны в мире. Отношение к собственным культурным ресурсам было очень показательным: «В то время как китайские политические элиты (тоже испытывавшие сложности с идеологической интерпретацией происходящего после распада СССР и падения коммунизма. - H. Ф.) традиционно предполагали не- 
сомненное превосходство китайской культуры... их российские коллеги сражались с наследием отсталости и предполагаемого более низкого положения в сравнении с развитым Западом» (Wilson, 2015: 1196).

В начале 1990-х годов доминировал вариант идентичности «Россия - это часть Европы», выдвинутый российскими западниками и инкорпорированный в официальный дискурс», - отмечает В. Феклюнина (Feklyunina 2015: 11). Но при этом «большинством вариантов российской идентичности, включая официальный курс, разделялась версия России как великой державы...» (там же). После распада Советского Союза Россия искала тесных связей с Западом и западной идентичностью, но попытки проецировать имидж страны на уровне государственной стратегии как в отношении западных стран, так и ближайших соседей отсутствовали: «В 1990-е Москва выдвигала достаточно непоследовательный нарратив некоторого естественного общего (постсоветского. - $H$. Ф.) пространства, не содержащий четких указаний на идентичность или четкого видения общих интересов» (там же: 9). Однако через десять лет в начале 2000-х годов Россия стала заниматься этими вопросами, начав с западных стран: проецируя на них нарратив России как страны, принадлежащей семье европейской цивилизации и являющейся партнером Запада (там же: 9). В целом идентичность России в 1990-х была кризисной, содержала элементы негативной идентичности, а мягкая мощь России оставалась настолько незначительной, что Аж. Най даже не упомянул о ней в своей книге о мягкой мощи. Отчасти это было следствием потери представлений об идентичности и невладения концептом мягкой мощи.

Как показывает В. Феклюнина, в конце 1990-х - начале 2000-х годов европейская идентичность России была выведена за рамки доминирующего дискурса, а его основой стало видение России как великой державы, геополитически равной Западу. В конце 2000-х - начале 2010-х годов по мере усиления кризисных явлений в отношении с Западом и отхода от идеи западной идентичности России и усиления идей национального суверенитета во внешней политике стала выдвигаться идея Русского мира. Аоминирующей идентичностью стала «Россия как уникальная цивилизация, ее нормативное превосходство по отношению к находящемуся в упадке Западу, с ее особой ответственностью за поддержание стабильности на постсоветском пространстве» (там же: 11).

Таким образом, применительно к российской ситуации можно говорить о процессуальности идентичности, которая отражала, в том числе, отношения России с Западом, а также неудачи процесса реформ. «Российская идентичность великой державы, определяющаяся двойственным отношением “любви-ненависти” с западными странами, повлияла на дуальность российского дискурса мягкой мощи, когда признаком великодержавного статуса и (мягкой) мощи считается одновременно как принятие дискурса гегемона, так и его отрицание», - отмечает британский исследователь Ю. Киселева (Kiseleva, 2015: 317).

В отношении Запада с начала 2000-х годов стала преобладать оппозиционная мягкая мощь, вытекающая из оппозиционности трактовки Россией собственной идентичности. Аля постсоветского пространства эти идеи привели к поиску оснований для евразийской интеграции, частью которой стала концепция «Русского мира». Эти нарративы идентичности были усилены их инструментальным продвижением разными акторами публичной дипломатии.

Ошибку мягкой мощи России В. Феклюнина видит в использовании Русского мира как объединяющей с Россией идеи для всей Украины. По ее мнению, нарратив Русско- 
го мира базируется на четырех положениях. Во-первых, русский мир представляется исторически сложившимся цивилизационным сообществом, характеристиками которого являются русский язык, православие и русская культура в целом. Во-вторых, идентичность Русского мира конструируется путем интерпретации «общего прошлого», понимаемого как общее происхождение ныне разных государств. «Великое прошлое противопоставляется ненормальности нынешнего разделения» (Feklyunina, 2015: 12). В-третьих, нарратив Русского мира создавал иерархические отношения между Россией и другими членами общего цивилизационного сообщества, где Россия занимала центральную позицию. При этом выдвигалась как идея многонационального цивилизационного пространства, где сходились культуры России, Украины и Беларуси, и других частей постсоветского пространства, так и идея российскоцентричного Русского мира, в котором принадлежность к Русскому миру подразумевала идентификацию с Россией, а не с Русью (там же). В-четвертых, коллективная идентичность Русского мира подразумевала наличие уникальной цивилизации, отличной как от Запада, так и от других цивилизаций (там же: $11-13$ ).

Однако у идей Русского мира, даже при их разнообразии, были серьезные ограничения. В. Феклюнина показывает, что идентичность Русского мира воспринималась на Украине по-разному. Она только частично совпадала с той частью населения Украины, воспринимающей свою страну как «альтернативную Европу», для которой значимы русский язык, русская культура и общее великое прошлое, и также с теми, кто поддерживал идею «Большой Европы», но отрицал доминирующую роль России в этом. Аля еще одной значительной части Украины, выражающей дискурс «Украина как Европа», такие идеи не были привлекательны (там же: 13-18). То есть мягкая мощь России и ее проецируемая идентичность не выполняли легитимизирующую функцию для Украины.

На наш взгляд, сведение российской идентичности к концепции Русского мира неправомерно. Оно исторически неглубоко и концептуально ограниченно. Эта концепция связана с определенной эпохой и состоянием внешней и внутренней политики. Она является не социокультурной константой, а категорией, носящей исключительно инструментальный характер, т. е. направленной на достижение определенных внешнеполитических результатов - усиления российской конкурентоспособности и процессов интеграции постсоветского пространства под руководством России. Кроме этого, такая трактовка коллективной идентичности не может привлечь те аудитории, которые ощущают себя далекими от России, например, тех, кто не является носителем православной идентичности, или тех, кто не говорит по-русски. Русский мир в такой интерпретации - это использование культурных констант и примордиальных кодов (хотя и заново сконструированных), с помощью которых можно привлечь ограниченное число людей.

Помимо достаточно спорной концепции Русского мира в этом виде, Россия, начиная с конца 2000-х годов, предпринимала много усилий по повышению собственной привлекательности в мире. К ним можно отнести языковые и культурные центры за рубежом, культурный обмен и ассоциации, обучение иностранных студентов, гуманитарную и международную помощь, использование привлекательности прецедентных феноменов русской высокой культуры (музыка, балет, опера, театр, живопись и др.). Однако российскую высокую культуру «трудно инструментализировать для практических целей», а «богатые культурные традиции часто находятся в тени негативных восприятий текущих политических событий, происходящих в стране» (Sergunin, 
Karabeshkin, 2015: 357). Возможности формирования мягкой мощи с помощью массовой культуры ограниченны: «В отличие от высокой культуры, современная российская популярная культура, стили жизни и медийные продукты кажутся менее привлекательными для иностранцев и даже для российских соотечественников» (там же). Однако особую роль в усилении российской интерпретации происходящего, формировании повестки дня и предпочтений на международной арене сыграли канал RT (ранее Russia Today - англ. «Россия сегодня») и агентство Sputnik, сопротивляющиеся медиагегемонии Запада.

Несмотря на то что развитие России в последние годы проходило через кризисы летитимности внутренней и внешней политики в глазах западных стран (украинский кризис, закрытие ряда оппозиционных СМК, предоставление убежища Сноудену, сирийский кризис, экономический кризис, допинговый скандал, обвинение России в хакерских атаках и попытке влияния на американскую внутреннюю политику и др.), мягкая мощь России стала расти. В 2016 г. британское агентство Portland Communications, составляющее рейтинг 30 стран мира, обладающих глобальной мягкой мощью, впервые включили в него Россию, которая заняла 27-е место. Первое место в рейтинге заняли США. Несмотря на то что методология данного исследования достаточно спорна, а само исследование является западоцентричным (в этот список не вкдючены, к примеру, Китай и Индия), можно говорить об определенных успехах, достигнутых российской мягкой мощью, которые заключаются в том, что Россия становится в глазах многих «полюсом притяжения для всех тех лиц, стран или компаний, которые хотят покинуть орбиту США» (Италия ... , 2016: Электронный ресурс) и продемонстрировать свою собственную идентичность. К основным ресурсам повышения привлекательности России аналитики относят телеканал RT, ведущий вещание на разных языках, дипломатию, которая является еще одной «сильной стороной России, которая принимает все более активное участие в урегулировании главных международных проблем (Сирия, Иран) и напрямую ведет переговоры с США» (Гринспан, 2016: Электронный ресурс). Страны здесь оценивались по нескольким параметрам, включающим культуру, вовлеченность в международные дела, цифровые технологии, правительство, образование, экономику и др. Россия находится достаточно высоко в этом рейтинге по таким аспектам, как «вовлеченность в международные дела» (8-е место), «цифровые технологии» (11-е место), и «культура» (14-е место). Аругие аспекты не получили высокой оценки. США заняли 1-е место по «цифровым технологиям», «культуре», «образованию».

Комментируя попадание России в этот список, С. Караганов заявил: «Россия одна из немногих стан мира, которая привлекает огромное количество людей стремлением к своей самостоятельности и суверенитету. Это огромный полюс притяжения. Наконец, мы поддерживаем традиционные ценности. ...Одна из причин недовольства нами коллегами на Западе как раз и заключается в том, что мы предоставляем другой, альтернативный и близкий большинству человечества вариант развития» (Чеснокова, 2016: Электронный ресурс). Необходимо отметить, что подобный результат может быть следствием как усиления оппозиционной и проективной мягкой мощи России, так и ослабления легитимизирующей функции мягкой мощи стран Запада, или одновременного осуществления обеих тенденций.

Американская исследовательница М. Ааруэль дает интересный анализ продвижения идей Русского мира и российской мягкой мощи в целом, в котором высказана мысль о том, что развиваемые Францией или США идеи публичной дипломатии схо- 
жи с российским пониманием и содержат в себе амбивалентные элементы. Например, идея франкофонов «базируется на французском языке, связана с национальным культурным наследием Франции и выполняет политическую задачу защиты “французского видения” или “французского голоса” на международной арене» (Laruelle, 2015: 23). Также эта идея «служит для оправдания... пост-колониальной политики... и для поддержки... сетей, защищающих французские коммерческие интересы и локальные элиты в регионе» (там же). В США эта политика сочетает лояльность к основополагающим ценностям американской демократии и продвижение этих ценностей за пределы страны посредством обширных сетей неправительственных организаций (НПО).

С американской мягкой мощью российскую роднит то, что Россия следует той же политике, что и США, в дипломатии с помощью НПО и медиа, защищая то, что она считает своими национальными интересами. Это хорошо выразила М. Ааруэль, показывая, что «идея Русского мира и ее все еще неохотный сдвиг от продвижения того, что является Россия-центричным (русские меньшинства за рубежом), к предложению повестки, основывающейся на системе ценностей, может быть понято как сходное с установленными традициями публичной дипломатии США» (там же). По ее мнению, Русский мир ни в коем случае не является этнической концепцией, а включает советское наследие, русскоговорящий мир и тех людей из разных стран, кто симпатизирует России. Концепция Русского мира, по мнению данного специалиста, оказалась успешной в мире пока в том отношении, что приступила к построению российского информационного пространства. Однако способность России продвигать экономическую и финансовую модель в ответ на принципы западного мирового порядка отмечаются \аруэль как гораздо менее успешные. По ее мнению, разделяемому рядом американских специалистов, концепция Русского мира может работать на повышение имиджа России в случае «способности России структурировать свой “голос" в мире» путем формулирования идеи, «выходящей за пределы национальной специфики, имеющей универсальную ценность и, таким образом, способной быть принятой, интегрированной и переинтерпретированной в других контекстах» (там же: 24). Как считает $\Lambda$ аруэль, Россия способна сформировать идеологическую платформу, базирующуюся на идеях консерватизма (там же). Россия может в конечном итоге добиться восприятия своей мягкой мощи, понимаемой американцами как оппозиционная, к признанию ее проективных и легитимизирующих функций в США и других странах. Этому способствуют имеющиеся основания для понимания российской идентичности как трансформирующейся, но имеющей ряд достаточно ясных оснований (ценности культуры, патриотизм, стремление модернизироваться, не лишившись собственного лица и пр.)

Подобную точку зрения разделяют и другие исследователи, считающие, что Россия пытается выработать «идеологический вызов и предложить альтернативу превалирующей западной гегемонии в области конструирования норм и ценностей в международной системе» (Wilson, 2015: 1198). Аж. Уилсон также полагает, что «после двух десятилетий... сознательного отрицания идеологии Путин пошел в другом направлении, пытаясь представить Россию как защитника “просвещенного консерватизма" и привлекательной альтернативы упадку западных либеральных норм и ценностей» (там же: 1190). Версия идеологии может быть иной, но полезно воспользоваться советом Аж. Ная о необходимости использования мягкой мощи, произведенной НПО, университетами, массовой культурой и другими субъектами гражданского об- 
щества. Русский исследователь Н. Силаев отмечает: «...уязвимость образа России за рубежом заключается в том, что это по преимуществу образ государственного аппарата, и именно с успехами бюрократии ассоциируются успехи страны... вызов состоит в том, сумеет ли бюрократия для начала хотя бы концептуально отделить свой собственный образ от образа нации, а затем сделать акцент на продвижении последнего» (Силаев, 2014: Электронный ресурс).

Таким образом, мягкая мощь США осуществляется с помощью легитимизирующей формы мягкой мощи и легитимизирующей идентичности, и ее кризисные явления связаны с определенной делегитимизацией действий США на международной арене и экономических трудностей внутри страны. Российская мягкая мощь выполняет оппозиционную и проективную функции по отношению к доминирующему мировому порядку, и ее реализация ограничивается прежде всего недостаточно артикулированной самоидентификацией. Продвижение мягкой мощи США и России иногда весьма затруднено.

Проективная мягкая мощь России могла бы быть усилена при выдвижении привлекательных для многих аудиторий ценностей, предпочтений и идеологии и при диверсификации посылов мягкой мощи. Здесь многое зависит от построения такой версии собственной идентичности, которая, проецируясь во внешний мир в виде мягкой мощи, будет привлекательной и создаст пространство новой «нормативной власти». Мы полагаем, что мягкая мощь выполняет некоторые функции внутри страны. Во внутрироссийской сфере функция мягкой мощи, скорее всего, заключается в том, чтобы легитимизировать для массового сознания внешнюю и внутреннюю политику страны. Кроме того, российская мягкая мощь, на наш взгляд, может выполнять и функцию усиления привлекательности России для разных культурных сообществ внутри страны при условии ее достаточной притягательности для всех групп населения.

\section{ЗАКАЮЧЕНИЕ}

Мы попытались проанализировать связь понятий мягкой мощи и идентичности, их значения в комплексе категорий, концептуализирующих культурный ресурс развития. Идентичность политизируется и воплощается в политику идентичности, направленную на победу идентичности или идентичностей определенного типа и вытекающей из нее (них) мягкой мощи. Мягкую мощь страны можно трактовать как производную от ее идентичности. Примеры США и России демонстрируют работу легитимизирущей, оппозиционной и проективной функций (или типов) мягкой мощи.

\section{СПИСОК АИТЕРАТУРЫ}

Гринспан, Э. (2016) Мягкая сила России растет [Электронный ресурс]// ИНОСМИ. 17 июня. URL: http://inosmi.ru/politic/20160617/236886539.html (дата обращения: 12.09.2016).

Италия: Самое большое оружие России - мягкая сила (2016) [Электронный ресурс] // REGNUM. 14 сентября. URL: https://regnum.ru/news/polit/2179418.html (дата обращения: 14.09.2016).

Най, Аж. (2006) Гибкая власть: как добиться успеха в мировой политике / пер. с англ. Новосибирск ; М. : ФСПИ Тренды. 221 с.

Силаев, Н. (2014) Как продать «Россию»? Почему не работает «мягкая сила» [Электронный peсурс]// Россия в глобальной политике. Т. 12. №1. URL: http://www.globalaffairs.ru/number/ Kak-prodat-Rossiyu-16405 (дата обращения 11.09.2016).

Уткин, А. И., Кузнецова, Т. Ф. (2010) История американской культуры. М. : Человек. 432 с. 
Федотова, Н. Н. (2015) Концептуальные средства анализа российской культуры // Знание. Понимание. Умение. № 4. С. 36-53. DOI: 10.17805/zpu.2015.4.4

Чеснокова, Е. (2016) Политолог: Россия заслуживает более высокого места в рейтинге «мягкой силы» [Электронный ресурс] // РИА Новости. 14 июня. URL: https://ria.ru/politics/ 20160614/1447147413.html (дата обращения: 14.09.2016).

Calleo, D. P. (2009) Follies of Power: America's Unipolar Fantasy. Cambridge : Cambridge University Press. $188 \mathrm{p}$.

Castells, M. (2010) The Power of Identity. Malden, Oxford: Willey-Blackwell. 584 p.

Eisenstadt, S. N. (2003) The construction of collective identities and the continual reconstruction of primordiality and sacrality - Some analytical and comparative indications // Comparative civilizations and multiple modernities : A collection of essays : in 2 vols. Leiden ; Boston : Brill. Vol. 1. 488 p. P. $75-134$.

Feklyunina, V. (2015) Soft power and identity: Russia, Ukraine and the "Russian world(s)" // European Journal of International Relations. September 24. P. 1-24. DOI: 10.1177/ 1354066115601200

Kiseleva, Yu. (2015) Russia's Soft Power Discourse: Identity, Status and the Attraction of Power // Politics. Vol. 35. No 3-4. P. 316-329. DOI: 10.1111/1467-9256.12100

Lehmann, J.-P. (2016) Collapse Of US Soft Power - Global Impacts [Электронный ресурс]// Forbes. 28 April. URL: http://www.forbes.com/sites/jplehmann/2016/04/28/the-collapse-of-ussoft-power-global-impacts/\#4934766b47e5 (дата обращения: 10.09.2016).

Laruelle, M. (2015) The "Russian World". Russia's Soft Power and Geopolitical Imagination. Washington: Center on Global Interests. 29 p.

Nye, J. S. (1990) Bound to Lead: The Changing Nature of American Power. New York : Basic Books. 307 p.

Nye, J. S. (2004) The Decline of America's Soft Power // Foreign Affairs. May - June. P. 16-20.

Nye, J. S. (2011) The Future of Power. New York : Public Affairs. 300 p.

Sergunin, A., Karabeshkin, L. (2015) Understanding Russia's Soft Power Strategy // Politics. Vol. 35. No 3-4. P. 347-363. DOI: 10.1111/1467-9256.12109

Wilson, J. L. (2015) Soft Power: A Comparison of Discourse and Practice in Russia and China // Europe-Asia Studies. Vol. 67. No. 8. P. 1171-1202. DOI: 10.1080/09668136.2015.1078108

Aата поступления: 03.10.2016 г.

\section{AN ANALYSIS OF CULTURAL RESOURCES: SOFT POWER AND IDENTITY \\ N.N. FEDOTOVA \\ (MGIMO-UNIVERSITY)}

The article analyses the notions of 'soft power' and 'identity' and their role in conceptualizing the cultural resources of development. It follows in the wake of our previous studies of various aspects of soft power, such as 'identity', 'cultural codes and constants' and 'cultural and symbolic capital'.

We show that a nation's soft power can be explained as a function of its identity. Using the terminology of identity's legitimizing, resistance and project types or functions as theorized by M. Castells, we provide a characteristic of Russia's soft power. These three functions of identity, extrapolated on soft power, use culture's precedent phenomena, cultural constants and capital, identity and cultural codes, as well as other phenomena, including some little-studied, as building blocks.

We also analyze the importance of culture, external and internal policy for shaping soft power. Russia's soft power is shown as resistance and project-type vis-á-vis the dominating world order and at the same time, legitimizing for Russia's internal context. This is a crucial factor in avoiding international conflicts, since in the age of nuclear weapon, the policy of containment by means of power balance does not provide an absolutely reliable deterrent. We conclude by outlining the history of US and Russia's soft power and its landmarks since 1990, as well as the limits of its influence.

Keywords: soft power; identity; culture; resource; Russia; USA; legitimizing soft power; resistance soft power; project soft power 


\section{REFERENCES}

Greenspan, E. (2016) Miagkaia sila Rossii rastet. INOSMI, 17 June [online] Available at: http://inosmi.ru/politic/20160617/236886539.html (access date: 12.09.2016). (In Russ.)

Italiia: Samoe bol'shoe oruzhie Rossii - miagkaia sila (2016). REGNUM, 14 September [online] Available at: https://regnum.ru/news/polit/2179418.html (access date: 14.09.2016). (In Russ.)

Nye, J. S. (2006) Gibkaia vlast': kak dobit' sia uspekba v mirovoi politike. Novosibirsk, Moscow, FSPI Trendy. 221 p. (In Russ.)

Silaev, N. (2014) Kak prodat' «Rossiiu»? Pochemu ne rabotaet «miagkaia sila». Rossiia v global' noi politike, vol. 12, no. 1 [online] Available at: http://www.globalaffairs.ru/number/Kak-prodatRossiyu-16405 (access date: 11.09.2016). (In Russ.)

Utkin, A. I. and Kuznetsova, T. F. (2010) Istoriia amerikanskoi kul'tury. Moscow, Chelovek. 432 p. (In Russ.)

Fedotova, N. N. (2015) Kontseptual'nye sredstva analiza rossiiskoi kul'tury. Znanie. Ponimanie. Umenie, no. 4, pp. 36-53. DOI: 10.17805/zpu.2015.4.4 (In Russ.)

Chesnokova, E. (2016) Politolog: Rossiia zasluzhivaet bolee vysokogo mesta v reitinge «miagkoi sily». RIA Novosti, 14 June [online] Available at: https://ria.ru/politics/20160614/1447147413.html (access date: 14.09.2016). (In Russ.)

Calleo, D. P. (2009) Follies of Power: America's Unipolar Fantasy. Cambridge, Cambridge University Press. 188 p.

Castells, M. (2010) The Power of Identity. Malden, Oxford, Willey-Blackwell. 584 p.

Eisenstadt, S. N. (2003) The construction of collective identities and the continual reconstruction of primordiality and sacrality - Some analytical and comparative indications. In: Comparative civilizations and multiple modernities : A collection of essays : in 2 vols. Leiden; Boston: Brill. Vol. 1. 488 p. P. 75-134.

Feklyunina, V. (2015) Soft power and identity: Russia, Ukraine and the "Russian world(s)". European Journal of International Relations, September 24. P. 1-24. DOI: $10.1177 / 1354066115601200$

Kiseleva, Yu. (2015) Russia's Soft Power Discourse: Identity, Status and the Attraction of Power. Politics, vol. 35, no 3-4, pp. 316-329. DOI: 10.1111/1467-9256.12100

Lehmann, J.-P. (2016) Collapse Of US Soft Power - Global Impacts. Forbes, 28 April. URL: http://www.forbes.com/sites/jplehmann/2016/04/28/the-collapse-of-us-soft-power-globalimpacts/\#4934766b47e5 (access data: 10.09.2016).

Laruelle, M. (2015) The "Russian World". Russia's Soft Power and Geopolitical Imagination. Washington: Center on Global Interests. 29 p.

Nye, J. S. (1990) Bound to Lead: The Changing Nature of American Power. New York, Basic Books. 307 p.

Nye, J. S. (2004) The Decline of America's Soft Power. Foreign Affairs, May - June, pp. 16-20.

Nye, J. S. (2011) The Future of Power. New York, Public Affairs. 300 p.

Sergunin, A., Karabeshkin, L. (2015) Understanding Russia's Soft Power Strategy. Politics, vol. 35, no 3-4, pp. 347-363. DOI: 10.1111/1467-9256.12109

Wilson, J. L. (2015) Soft Power: A Comparison of Discourse and Practice in Russia and China. Europe-Asia Studies, vol. 67, no. 8, pp. 1171-1202. DOI: 10.1080/09668136.2015.1078108

Submission date: 03.10.2016.

Федотова Надежда Николаевна - доктор социологических наук, профессор кафедры социологии Московского государственного института международных отношений Министерства иностранных дел России. Адрес: 119454, Россия, г. Москва, пр. Вернадского, д. 76. Тел.: +7 (495) 434-94-26. Эл. aspec: nnfedotova@rambler.ru

Fedotova Nadezhda Nikolaevna, Doctor of Sociology, Professor, Department of Sociology, MGIMO-University. Postal address: 76 Vernadsky Prosp., Moscow, Russian Federation, 119454. Tel.: +7 (495) 434-94-26. E-mail: nnfedotova@rambler.ru 